\title{
Business Environment Effect on Formalization Willingness and Registration Decision of SMEs in Ivory Coast
}

\author{
Traore Nohoua \\ University Alassane Ouattara of Bouaké
}

This paper analyses the effects of the business environment on the formalisation provision and the decision to register small and medium enterprises (SMEs) in Ivory Coast, based on informal sector survey data collected in the cities of Abidjan, San-Pedro and Daloa. The study is based on descriptive analyses and estimation of a Probit model with selection. The analysis reveals that procedural complexity, information asymmetry and geographical location are the factors that significantly determine both the formalisation disposition and the decision to register businesses. It appears that, in addition to the business environment, subcontracting and the size of SMEs explain the decision to register them, while the possession of a business plan, access to infrastructures and markets are the determinants of formalisation. Thus, it appears that, in an integrated approach, the strengthening of tax incentives for SMEs operating in low-profit localities, the formalisation of subcontracting relationships, the dematerialization of procedures and the popularisation of reforms are proving to be a guarantee of the formalisation of informal activities.

Keyword: business environment, formalization, registration decision, SMEs, Ivory Coast

\section{INTRODUCTION}

According to the legalistic thesis, the weight of State rules and administrative constraints on micro and small enterprises discourages initiative and dissuades them from formalising their existence. In this sense, Loayza (1999) and De Soto (2000) argue that excessive regulation and high tax rates and social charges reduce the profitability margin of the formal sector and encourage entrepreneurs to move into the informal sector. As a result, the development of small business would be highly dependent on the business environment.

Côte d'Ivoire, aware of the possible negative effects of a deleterious business environment on enterprise growth, has rightly initiated reforms since 2012 to improve its business environment in order to foster the development of a dynamic and internationally competitive private sector. The results obtained over the 2012-2015 period show significant progress in improving the business environment. Thus, Ivory Coast was ranked among the ten (10) most competitive economies in Africa and was designated as the most attractive country in Sub-Saharan Africa for investment.

However, this country, which is regularly cited among the most reformist countries, fell four places in 2019 compared to 2018, occupying $118^{\text {th }}$ place out of 141 countries (World Bank, 2019). This regression comes at a time when the effects of these reforms should be felt in terms of the dynamism of formal entrepreneurship. Thus, it becomes timely to examine the role of the business environment in the decision 
of managers to formalise their production units in the context of an economy marked by the predominance of informal activity.

Already in 2012, the Studies and Job Promotion Agency (AGEPE) estimated that $96.5 \%$ of informal activities were operating on the fringes of public administration services and therefore do not appear in the State's registers (AGEPE, 2012). In addition, almost all (93.8\%) of jobs are informal according to the estimates of the Integrated Regional Survey on Employment and the Informal Sector (ERI-ESI, 2017). Although the need to migrate this part of the economy to the formal sector is no longer in evidence, it seems to be hampered by the constraints linked to the business environment.

Even if most studies indicate that a significant proportion (over 70\%) of managers would be willing to formalise their enterprises, this propensity does not seem to translate in practice into the registration of production units, basically due to the inability of the state to create a business environment conducive to the registration of economic activities. While their registration is to some extent indispensable for their access to certain services offered by the public authorities and development partners, such as the supervision services of the certified Management centers (CGAs), training programmes, support funds for the development of their activities and more recently the COVID-19 support fund for SMEs, notably the support fund for the informal sector (FASI). Their limited access to these services could be seen as one less factor of production for these enterprises unknown to the public authorities. It therefore becomes reasonable to take an interest in their administrative affiliation. Faced with this situation, there is a pressing need to find a solution in order to encourage more informal enterprises to register with the administration, with a view to facilitating their access to the productive resources that guarantee their growth. Better still, it seeks to answer the following questions:

- How does the business environment influence the formalisation provision and the decision to register micro and small informal enterprises (MSEIs)?

- What factors related to the business environment determine both the formalisation disposition and the registration decision of SMEs?

This study is innovative in that it looks at the business environment factors that determine both the formalisation disposition and the decision to register SMEs. This is in contrast to most research in this field of investigation which analyses these two dimensions separately, whereas a joint analysis would allow the development of more refined policy implications for the benefit of policy makers.

The objective of this study is to determine both the factors of formalization and the decision to register informal enterprises, under the assumption that a business environment conducive to economic activity would ensure the coincidence of the formalization provision and the registration decision. To achieve this objective, the study estimates a Probit model with selection, inspired by Heckman (1979) from data from the survey carried out by the Economic policy analysis Unit of the Ivorian center for economic and social research (CAPEC), within the framework of the CAPEC/IDRC research project on the determinants of the performance of enterprises in French-speaking sub-Saharan Africa.

This article is composed of four parts. The first part is devoted to the analysis of the formalisation and registration of enterprises in the literature. The second part deals with the methodological approach. The third part presents the results of the study, followed by their interpretation and discussion in the fourth part.

\section{THE ANALYSIS OF THE FORMALIZATION AND REGISTRATION OF SMES IN THE LITERATURE}

\section{Analysis of Thinking School}

Many theoretical approaches dealing with the problem of formalization and registration of companies have been highlighted in the literature. The present analysis focuses on neo-liberal, legalistic and structuralist approaches. In the neo-liberal approach, the informal sector is seen as the result of government regulations that are costly to entrepreneurs, such as health care mandates, high minimum wages, lengthy filing procedures and collective agreements (De Soto, 1989). As a result, working in the informal sector is seen as a voluntary strategy where knowledgeable entrepreneurs could start their businesses at low cost. 
According to neo-liberalism, this explains why a large proportion of operators refuse to collaborate with the state and are categorically reluctant to work with administrative registers.

In the same vein, the legalistic current maintains that keeping companies in the informal sector would reflect the deliberate will of economic operators to escape this yoke and regain their freedom. Indeed, they seek to escape the weight of legality in order to adopt new productive strategies to maximize their profit. But the structuralist approach, inspired by Marxism, nuances the assertions of the two previous ones. While admitting that laws and regulations on economic activities are unsuitable for the informal sector, this current of thought points out that the best solution is not to abolish them but rather to improve them. For the proponents of this approach, these legislations are considered useful to protect the common interests of the economy as a whole and to enable community projects to be carried out with collective resources.

Thus, aware of the importance of these roles of the State, a significant component of operators does not refuse to cooperate with it. Non-registration appears to be independent of the operators' will and is largely the result of administrative, economic, social and geographical constraints. As a result, advocates of the structuralist approach recommend structural reform of public registration services to make them more efficient and accessible. This includes making the processing of files shorter, less corrupt, more transparent, less costly in terms of low financial cost, simpler procedures and closer services (Rakotamanana, 2009).

\section{Empirical Investigation of Explanatory Factors}

The issue of formalization of companies has been the subject of numerous studies. Some of these studies have focused on the factors of formalization by analyzing the factors that keep firms in the informal sector, the factors influencing the decision to formalize or the determinants of the disposition to formalize. Others have focused on the effects of the business environment and formalization programs.

\section{The Role of the Business Environment in Formalization and the Registration Decision}

Many studies have shown that companies are forced to operate in the informal sector. For Benjamin and Mbaye (2012), in general, the administrative burdens and complexity of regulations, rigid labor laws, and high tax rates that weigh heavily on African firms force them to join the informal economy. This explanation is shared by Ishengoma and Kappel (2006), who show that external factors such as limited access to financial or business development services, small markets, insufficient economic infrastructure and public services, or complex and burdensome regulations discourage formalization.

Also, Benjamin and Mbaye (2012) identify the inability of the judiciary to enforce laws and contracts, weak administration, and corruption as widespread characteristics in Africa that combine to create strong incentives for entrepreneurs to join the informal economy. In the same vein, Ouédraogo et al. (2011) show that direct registration costs and asymmetric information are very constraining, especially for IPUs in the main agglomerations of WAEMU countries.

The conclusions of many authors (De Soto, 1994; Djankov et al 2002; Lautier, 2004) reveal that the informal economy persists in developing countries because of the excessive weight of the State, not only in fiscal matters, but especially in terms of administrative regulations relating to the creation of formal enterprises, with often restrictive, useless and bureaucratic procedures.

Moreover, the United States Agency for International Development (USAID, 2005) justifies the informality of firms by regulatory constraints, administrative burdens, fees and financial obligations, corruption in public administration, socio-cultural attitudes, the absence of important services without firms and criminality that hamper the formalization of firms. Also for Dabla-Norris et al (2008), firms choose to integrate the informal economy to avoid the costs associated with regulation in the formal economy. Steel and Snodgrass (2008) and Verick (2006) also confirm that lack of access to public services is a determining factor in the expansion of the informal economy. Farrell (2004) attributes the informality of the firm to red tape. In fact, he notes that among the main factors that motivate firms to not comply with regulations are tax and social security contributions. In the same vein, Ouédraogo (2017) demonstrates that there is a close link between governance, corruption and the informal economy. Thus, a poor institutional framework would encourage the growth of the informal sector. 
Furthermore, some authors have focused on the determinants of the decision to formalize. From the perspective of economic rationality, the choice between the formal and the informal economy would be based on a comparison of the costs and benefits of formalization. In this sense, La Porta and Schleifer (2008) point out that the decision to formalize results from a comparison of costs and benefits. In addition, Perry et al (2007) and Kanbur (2009). and Gelb et al (2009) argue that firms opt for formality when access to public services and credit is favourable and when regulations on tax payment and business registration are rigorously enforced.

Regarding public services, Gelb et al (2009) also find that firms opt for formality when access to public services is favourable. From this perspective, the analysis of Traoré (2018) shows that access to basic services such as water and electricity boosts the formalization of firms. These results are somewhat qualified by De Mel et al (2012) who showed, through an experimental study in Sri Lanka on the demand for formalization, that providing information and reimbursing registration costs does not encourage firms to register. However, Traoré (2019) shows that registration costs and ignorance of procedures constitute institutional barriers to the formalization of informal SMEs in Côte d'Ivoire.

Other studies have particularly highlighted the effects of regulations on the formalization decision. In general, when this environment is conducive to business, it boosts formalization. Conversely, managers are reluctant to declare their production units. Thus, in a study of a sample of 85 countries, Djankov et al (2002) find a strong positive correlation between the number of procedures required to set up a business and the size of the informal economy. Some authors, such as Ingram et al (2007), have rightly estimated a Probit model in which the perception of constraints in the business environment determines the choice of firms to evolve in the formal or informal sector.

As shown by Rakotomanana (2009), having difficulties in accessing credit increases the probability that operators will agree to register their establishment for the first time on an administrative register. In this sense, Traoré (2016) argues that financing and market problems lead SMEs to formalization. Analyzing regulation, Branstetter et al. (2010) show that lighter regulation on market penetration makes it possible to increase the number of company registrations, even if this phenomenon affects more employees who set up on their own account and very small marginal companies with a limited lifespan.

On the contrary, Friedman et al (2000) and Johnson et al, (2000) argue that exacerbated corruption can discourage the registration of informal activities. In this vein, Maldonado (2000) estimates that very high registration costs and delays, the complexity of administrative procedures, and the inadequacy of existing regulations to the needs of the informal sector are all factors that discourage micro-entrepreneurs from legalizing their business.

Also, an institutional framework unsuitable for economic activity is attributed by many authors to the weight of the State. Indeed, studies observe that, in most African countries, the capacity of governments to impose regulatory constraints on the activity of informal enterprises is limited (Trip, 1997; Heilman, 1998). In seeking to legislate in this area, the main effect induced by the government is to put the legal status out of reach of a large number of small firms. Thus, some analyses show that institutional constraints are sources of transaction costs (North, 1990; Acemoglu, 2007; Talbot, 2008).

In addition, government institutions represented by legislation, regulations, and administrative culture tend to increase transaction costs (De Soto, 1994, Afibefun and Daramola, 2003). Moreover, La Porta and Schleifer (2008) find a negative link between the cost of complying with labour legislation and the cost of red tape on formalization. Similarly, Ingram et al (2007), indicate a strong correlation between formality and certain attributes of the business climate such as access to electricity, finance and land.

Regarding formalization policies, Bruhn (2011) finds that the program of rapid opening of companies in Mexico has led to a 5\% increase in the number of registered companies. Similar results have been obtained by other studies such as that of Bettcher et al (2009) which showed that the simplification of business licensing procedures in Peru led to an increase in the number of registered companies of $120 \%$ between 1993 and 1996. Similarly, Klapper et al (2007) find that the simplification of business registration through electronic procedures in Guatemela, Sri Lanka and Jordan increased registrations by more than $20 \%$. 


\section{Managers' and Companies' Marks on the Formalization and Decision of Registration}

Looking at the characteristics of the production unit and the manager, Rakotomanana (2009) indicates that the willingness to register is positively affected by the male gender and the degree of "visibility" of the production unit. Nevertheless, Fomba (2013) shows, in the case of Cameroon, that being a female entrepreneur increases by $2.8 \%$ the probability of a company being partially formal. This result is somewhat nuanced by the analysis of Traoré (2016) which shows, in the case of Côte d'Ivoire, that the fact that the SME is run by a woman decreases the probability of its formalization. Furthermore, Lapeyre and Lemaitre (2014) show that the lack of support from the financial system and training programs that are not adapted to their specificities constitute barriers to formalization. Similarly, according to these authors, inter-firm factors such as the existence of limited or exploitative relationships and the weakness of professional associations contribute to keeping firms in the informal sector. In this sense, the results of Rakotomanana (2009) show, in the case of Madagascar, a positive effect of formal vocational training on the willingness of informal enterprises to register.

Moreover, Ouédraogo et al (2011) show that firms willing to formalize usually have a minimum critical size in terms of capital endowment, realized value added and labor force, as well as a mode of organization and production that obliges them to comply with this provision. Fajnzylber et al. (2006) find, in a study of Mexican microenterprises, that the decision to formalize increases with firm size. A similar result was found by Traoré (2019), who indicates that the decision to formalize is positively correlated with the size of SMEs in Ivory Coast. However, McKenzie and Woodruff (2006) argue that formality for microenterprises is not relevant. These authors, using a survey of informal microenterprises in Mexico, show that $75 \%$ of them explain their informality by their small size, and consider this choice optimal. These analyses of firm size are in line with legalistic thinking, which considers that the informal sector is made up of microentrepreneurs who prefer to operate informally to escape economic regulations (De Soto, 1994).

\section{METHODOLOGICAL APPROACH}

The study uses a quantitative approach, through descriptive analysis and econometric modeling. This section highlights the data used, presents the econometric model and estimation method, and the strategy for selecting instrumental variables.

\section{Study Data}

The data used in this analysis is based on a sample of 400 informal sector firms from the cities of Abidjan, San Pedro, and Daloa. These cities were selected on a reasoned basis. Indeed, these are the first three cities with the highest number of firms at the time of the survey. The sample for the survey was based on information provided by the municipal authorities and the INS (National Institute of Statistics).

On the subject of the concentration of economic activities, a list of municipalities/neighborhoods with a high concentration of IPUs has been drawn up. In the city of Abidjan, six districts were selected. In each neighborhood, two Enumeration Areas (EAs) were located using the mapping provided by the INS. For the cities of Daloa and San-Pedro, three districts were respectively selected with the help of the communal authorities.

The data was collected from companies in the informal sector in 2014. The econometric study is part of a binary model in which a specific part of the sample is observed. The model used is by Van De Ven and Van Praag (1981) inspired by Heckman (1979) in which the equation of interest is of a dichotomous nature.

\section{The Econometric Model}

The model is as follows:

$Y_{1}$ and $Y_{2}$ two dichotomous variables such as $Y_{2}$ is observable only if $Y_{1}=1$.

In our case, 
$Y_{1}$ if the manager is willing to formalize his company and 0 otherwise

$Y_{2}$ if the manager has started the registration process of his company and 0 otherwise

Assuming that $Y_{1}^{*}=Z^{\prime} \gamma+\eta$ is an unobservable latent variable of utility in the face of dichotomous choices (willingness to formalize or not), then we suppose that

$$
Y_{1}=1 \text { (the choice is observed) only if } Y_{1}^{\prime}>0 \text { and } Y_{1}=0 \text { otherwise }
$$

In the event that

$Y_{1}=1$ the individual has to face a binary second choice

$Y_{2}$ and $Y_{2}^{*}=X^{\prime} \beta+\varepsilon$ can be seen as an unobservable latent utility variable in the face of the binary second choice (the decision to register or not).

In this case, $Y_{2}=1$ if $Y_{2}^{*}>0$ and $Y_{2}=0$ if $Y_{2}^{*}<0$. By introducing $\beta$ and $\gamma$ to explain the latent propensities of binary choices 1 and 2 , one can define a system of two equations.

\section{The first equation is the selection equation:}

$$
\text { - } \operatorname{probit}\left(Y_{1}=1 \mid \gamma\right)=z_{i} \gamma
$$

$Y_{1}^{*}$ can be represented by a probit model in which the disposition to be formalized $\left(Y_{1}=1\right)$ is explained by a set of factors such as the vectors $M_{i}, E_{i}$ and $C_{i}$. These vectors represent respectively the characteristics of the manager, the company and the business environment.

$$
\mathrm{dispo}_{\text {formal }}=\gamma_{0}+\gamma_{1} M_{i}+\gamma_{2} \mathrm{E}_{i}+\gamma_{3} C_{i}+\eta_{i}
$$

The second equation is the main equation. It is defined only if $Y_{1}=1$ :

$$
-\operatorname{probit}\left(Y_{2}=1 \mid \beta\right)=x_{i} \beta
$$

$Y_{2}^{*}$ can be represented by a probit model in which the decision to register $\left(Y_{2}=1\right)$ is explained by a set of explanatory factors such as $M i, E i$ and $C i$ which respectively represent the characteristics of the manager, the company and the business environment.

$$
\begin{gathered}
\text { decis }_{\text {enregis }}=\beta_{0}+\beta_{1} M_{i}+\beta_{2} \mathrm{E}_{i}+\beta_{3} C_{i}+\varepsilon_{i} \\
\eta_{i} \sim N(0,1) \\
\varepsilon_{i} \sim N(0,1) \\
\operatorname{corr}\left(\mu_{i} \varepsilon_{i}\right)=\rho
\end{gathered}
$$

The couple $\left(\eta_{i} ; \varepsilon_{i}\right)$ follows a two-dimensional normal law $N\left(\left(\begin{array}{l}0 \\ 0\end{array}\right) ;\left(\begin{array}{ll}\rho & 0 \\ 0 & \rho\end{array}\right)\right), \rho$ designates the coefficient of linear correlation between the two error terms.

\section{Model Estimation Method}

The estimation is done in two steps using the maximum likelihood estimator. In the second equation, the Mills ratio proposed by Heckman is introduced in order to correct for possible selection bias. However, the correction is made only after the Chi2 on the correlation coefficient of the error terms of the two equations $R h o$. The results of this study were used to identify the proven existence of selection bias.

The test of the Chi2 checks whether $\rho$ is significantly different from $0\left(H_{0}: \rho=0\right)$. The rejection of the null hypothesis (P-value $<0.05$ if critical threshold at 5\%) means that the equation of interest is not 
independent of the selection equation; the two decisions are not made independently of each other, so the correction of the selection bias is justified.

\section{Selection Strategy for Instrumental Variables}

The selection equation must include the same independent variables as those in the main equation, as well as some additional instrumental variables that are supposed to affect the dependent variable in the selection equation, but not the dependent variable in the main equation. In other words, the instrumental variables should be able to affect the willingness to formalize firms, not the decision to register a business.

The variables in our sample, which were presumed to be instrumental variables, are goodwill, the mode of creation, the age of the manager and access to the public market. The implicit hypothesis that justifies the choice of these instrumental variables is that they influence formalization, but without direct effect on the registration decision. The impact of the identification variables on the selection equations (willingness to formalize) and on the main equation (registration decision) is apprehended through the coefficients of the Probit models.

TABLE 1

TESTING THE IMPACT OF THE IDENTIFYING VARIABLES

\begin{tabular}{lll}
\hline & Disposition to be formalized & Decision to be registered \\
\hline Business & $2,1810-8 *$ & $9.7010-8 \mathrm{NS}$ \\
Business Plan & $0,77 * * *$ & $-0.306 \mathrm{NS}$ \\
Access to the public market & $0,754 * * *$ & $0.249 \mathrm{NS}$ \\
Age of the manager 2 & $-0,001 * *$ & $-0,000 \mathrm{NS}$ \\
Observation & $\mathbf{3 9 2}$, & $\mathbf{2 7 6}$ \\
$* * *$ significant at 1\%*** significant at 1\%*** significant at 1\%*** significant at 1\%*** significant at 1 \\
\hline
\end{tabular}

Source: Author based on CAPEC_CRDI 2013 data

\section{THE RESULTS OF THE STUDY}

This section is devoted to the presentation of the results of the statistical analysis resulting from the crossing of variables and those of the econometric investigation inherent in the estimation of the Probit model with selection.

\section{Descriptive Statistics}

The results of the descriptive statistics are provided in Table 2.

TABLE 2

\section{REGISTRATION DECISION CHARACTERIZATION}

\begin{tabular}{|l|l|l|l|l|}
\hline Variable name & Terms and Conditions & $\begin{array}{l}\text { Min } \\
\text { max }\end{array}$ & $\begin{array}{l}\text { Percentage or } \\
\text { average* }\end{array}$ & $\begin{array}{l}\text { \% of companies in } \\
\text { the process of } \\
\text { registration }\end{array}$ \\
\hline Business Environment & & 27,25 & \\
\hline Corruption & 1 Severe problem & 72,75 & 12,44 \\
& 0 No problem & & 54,25 & 8,97 \\
\hline Public Market & 1 Major problem & 45,75 & 11,27 \\
& 0 No problem & & 26,50 & 11,54 \\
\hline Perception of \\
procedures & 1 Complexes & 73,50 & 10,61 \\
\hline High level of taxes & 0 Single & & 12,75 & 11,74 \\
\hline & 0 Yes & 87,25 & 12,82 \\
\hline
\end{tabular}




\begin{tabular}{|c|c|c|c|c|}
\hline \multicolumn{5}{|l|}{ The Manager } \\
\hline Age of the manager & Quantitative & $\begin{array}{l}15 \\
57\end{array}$ & 34,89 & \\
\hline Origin & $\begin{array}{l}\text { 1 Ivorian } \\
0 \text { Otherwise }\end{array}$ & & $\begin{array}{l}33 \\
67\end{array}$ & $\begin{array}{l}13,30 \\
7,69\end{array}$ \\
\hline Level of education & $\begin{array}{l}0 \text { None } \\
1 \text { Primary } \\
2 \text { Secondary and higher }\end{array}$ & & $\begin{array}{l}43,50 \\
32,50 \\
24,00\end{array}$ & $\begin{array}{l}8,13 \\
13,33 \\
15,15\end{array}$ \\
\hline Technical training & $\begin{array}{l}1 \text { Having received } \\
\text { technical training } \\
0 \text { Without technical } \\
\text { training }\end{array}$ & & $\begin{array}{l}34,50 \\
65,50\end{array}$ & $\begin{array}{l}14,89 \\
9,73\end{array}$ \\
\hline Sex & $\begin{array}{l}1 \text { Woman } \\
\text { 0 Male }\end{array}$ & & $\begin{array}{l}28 \\
72\end{array}$ & $\begin{array}{l}10,14 \\
11,9\end{array}$ \\
\hline $\begin{array}{l}\text { Administrative } \\
\text { formality }\end{array}$ & $\begin{array}{l}1 \text { Ignore } \\
0 \text { Known }\end{array}$ & & $\begin{array}{l}37,25 \\
62,75\end{array}$ & $\begin{array}{l}1,98 \\
16,85\end{array}$ \\
\hline \multicolumn{5}{|l|}{ The company } \\
\hline Size & $\begin{array}{l}0 \text { Microenterprise } \\
1 \text { Small business }\end{array}$ & & $\begin{array}{l}98,25 \\
1,75\end{array}$ & $\begin{array}{l}10,95 \\
40\end{array}$ \\
\hline $\begin{array}{l}\text { Number of } \\
\text { employees }\end{array}$ & $\begin{array}{l}0 \text { Without employee } \\
11 \text { to } 3 \text { employees } \\
2 \text { More than } 4 \text { employees }\end{array}$ & & $\begin{array}{l}47,25 \\
43,25 \\
9,25\end{array}$ & $\begin{array}{l}11,11 \\
11,48 \\
12,90\end{array}$ \\
\hline Location & $\begin{array}{l}0 \text { Abidjan } \\
1 \text { San-Pedro } \\
2 \text { Daloa }\end{array}$ & & $\begin{array}{l}50 \\
25 \\
25\end{array}$ & $\begin{array}{l}4,92 \\
12,66 \\
20,51\end{array}$ \\
\hline $\begin{array}{l}\text { Establishment of } \\
\text { an account }\end{array}$ & $\begin{array}{l}0 \text { Does not keep records } \\
1 \text { Keeps accounts }\end{array}$ & & $\begin{array}{l}13,50 \\
86,50\end{array}$ & $\begin{array}{l}10,33 \\
18,92\end{array}$ \\
\hline Subcontracting & $\begin{array}{l}0 \mathrm{No} \\
1 \mathrm{Yes}\end{array}$ & & $\begin{array}{l}72 \\
18\end{array}$ & $\begin{array}{l}12,28 \\
7,84\end{array}$ \\
\hline Business & Quantitative & & 638496,3 & \\
\hline Creation mode & $\begin{array}{l}0 \text { Created without a } \\
\text { business plan } \\
1 \text { Created with business } \\
\text { plan }\end{array}$ & & $\begin{array}{l}66,50 \\
33,50\end{array}$ & $\begin{array}{l}11,18 \\
12,26\end{array}$ \\
\hline $\begin{array}{l}\text { Use of } \\
\text { infrastructure } \\
\text { (Water and } \\
\text { Electricity) }\end{array}$ & $\begin{array}{l}0 \mathrm{No} \\
1 \mathrm{Yes}\end{array}$ & & $\begin{array}{l}53,13 \\
46,87\end{array}$ & $\begin{array}{l}9,27 \\
14,06\end{array}$ \\
\hline Total & & & & 11,47 \\
\hline
\end{tabular}

Source: Author based on CAPEC_CRDI 2013 data

Table 2 presents descriptive statistics for the variables in the econometric model, including characteristics of firms, managers and the business environment. They highlight the distinguishing characteristics of the firms that started the registration process. The analysis focuses first on the business environment, then on the characteristics of the manager and finally on those of the firm.

Characterization of the Registration Decision in Relation to the Business Environment

The results indicating the analysis of corruption show that $8.97 \%$ of managers who consider it as a severe problem in the conduct of their business, have started the process of registering their company against $12.44 \%$ of those who find no problem. Regarding access to markets, the results indicate that $11.54 \%$ 
of the companies with a problem of access to public markets have started to register against $11.27 \%$ of those who do not have this problem.

Concerning the perception of the high level of taxes, the results show that $12.82 \%$ of managers who consider them high are in the registration phase against $11.25 \%$ who do not have this apprehension. Regarding the perception of procedures, $10.61 \%$ of managers who consider them complex have started to register their company against $11.74 \%$ of managers who do not have this perception.

\section{Characterization of the Record According to the Profile of the Managers}

The results show that only $7.69 \%$ of companies run by foreigners are in the process of registering against $13.30 \%$ of companies run by Ivorians. With regard to the educational level of the manager, the data indicate that $15.15 \%$ of managers with the higher level of education have started the registration of their business, compared to those at the primary level and illiterate people estimated at $13.33 \%$ and $8.13 \%$ respectively.

On the subject of technical training, $14.89 \%$ of managers who have received this training are determined to register, compared to managers who have not received any training in business skills. In addition, $11.9 \%$ of male managers decided to register their company compared to $10.14 \%$ of female managers. Regarding administrative formalities, only $1.98 \%$ of managers who were unaware of these formalities started to register their company compared to $16.85 \%$ of managers who were aware of the administrative formalities.

\section{Registration Characterization by Business Profile}

The statistics in Table 2 show that $11.47 \%$ of the companies in our sample are in the process of registration. It also shows that $40 \%$ of small enterprises are in the registration process compared to only $10.95 \%$ of microenterprises. Regarding the number of employees, $12.25 \%$ of the enterprises hiring at least four (4) employees are in the registration process, compared to $11.48 \%$ and $11.11 \%$ respectively for enterprises hiring between 1 and 3 employees and those with zero $(0)$ employees.

On the subject of location, companies located in the cities of Daloa and San-Pedro recorded the highest proportions of companies in the process of registration with respective proportions of $20.51 \%$ and $12.66 \%$ against only $4.92 \%$ of those located in Abidjan. With regard to the mode of bookkeeping, more firms $(18.92 \%)$ are starting to register while this rate is only $10.33 \%$ among those that do not keep any accounts.

As for companies that subcontract, $7.84 \%$ of those that do so are in the registration phase compared to $12.28 \%$ for those that do not subcontract. Moreover, $12.26 \%$ of companies whose managers had a business plan when they were created are in the process of registration, while this proportion represents $11.18 \%$ among companies created without a business plan. In addition, statistics show that less than a quarter $(14.06 \%)$ of the businesses that have access to infrastructure (water and electricity) are in the process of registering, compared to a lower proportion (11.18\%) of businesses that do not have access to its infrastructure.

\section{Factors Explaining the Formalization Provision and the Registration Decision}

This section highlights the presentation and discussion of the results. 
TABLE 3

RESULTS OF THE ECONOMETRIC ANALYSIS

\begin{tabular}{|c|c|c|c|c|}
\hline Variables & Coefficients & P- Value & Marginal Effects & P-Value \\
\hline \multicolumn{5}{|l|}{ REGISTRATION DECISION } \\
\hline Primary & 0,258 & 0,458 & 0,029 & 0,466 \\
\hline Secondary and higher & 0,256 & 0,337 & 0,038 & 0,355 \\
\hline Number of employees & 0,060 & 0,128 & 0,009 & 0,120 \\
\hline Woman & $-0,204$ & 0,452 & $-0,029$ & 0,430 \\
\hline San-Pedro & 0,519 & 0,088 & 0,059 & 0,091 \\
\hline Daloa & 1,25 & 0,000 & 0,210 & 0,000 \\
\hline Access to infrastructure (water and electricity) & 0,446 & 0,043 & 0,068 & 0,054 \\
\hline Ignore procedures & $-1,24$ & 0,001 & $-0,140$ & 0,000 \\
\hline Small business & 2,030 & 0,005 & 0,490 & 0,006 \\
\hline Subcontractor & $-0,65$ & 0,043 & $-0,080$ & 0,014 \\
\hline Problem of corruption & $-0,108$ & 0,703 & $-0,015$ & 0,693 \\
\hline Does not keep any records & $-0,197$ & 0,408 & $-0,031$ & 0,502, \\
\hline Complexity of procedures & $-0,491$ & 0,088 & $-0,066$ & 0,062 \\
\hline \multicolumn{5}{|l|}{ FORMALIZATION PROVISION } \\
\hline Primary & 0,094 & 0,638 & 0,018 & 0,635 \\
\hline Secondary and higher & 0,324 & 0,150 & 0,062 & 0,208 \\
\hline Number of employees & 0,023 & 0,607 & 0,004 & 0,606 \\
\hline Woman & $-0,278$ & 0,150 & $-0,057$ & 0,158 \\
\hline Business & $1,88 \mathrm{E}-07$ & 0,094 & $3,80 \mathrm{E}-8$ & 0,094 \\
\hline Business Plan & 0,774 & 0,000 & 0,151 & 0,000 \\
\hline San-Pedro & 0,419 & 0,076 & 0,085 & 0,068 \\
\hline Daloa & 0,438 & 0,063 & 0,088 & 0,053 \\
\hline Age of the manager & 0,093 & 0,098 & 0,018 & 0,089 \\
\hline Age of the manager squared & $-0,001$ & 0,053 & $-0,000$ &, 0450 \\
\hline Access to infrastructure (water and electricity) & 0,083 & 0,643 & 0,016 & 0,644 \\
\hline Ignore procedures & 0,090 & 0,623 & 0,018 & 0,624 \\
\hline Small business & 0,541 & 0,286 & 0,101 & 0,240 \\
\hline Subcontractor & $-0,148$ & 0,474 & $-0,030$ & 0,479 \\
\hline Problem of corruption & 0,198 & 0,302 & 0,039 & 0,292 \\
\hline Does not keep any records & 0,039 & 0,880 & 0,007 & 0,881 \\
\hline Complexity of procedures & 0,754 & 0,000 & 0,139 & 0,000 \\
\hline Problem of access to public markets & 2,13 & 0,000 & 0,514 & 0,000 \\
\hline
\end{tabular}

\section{INTERPRETATION AND DISCUSSION OF RESULTS}

The estimated model is globally significant at the $1 \%$ threshold with (Prob> chi2 $=0.000$ ). The significance of the coefficients is given through their respective probabilities (P-value) at the threshold of $1 \%, 5 \%$ and $10 \%$.

The study shows that location, access to infrastructure and company size are the factors that boost managers' propensity to register informal businesses. The location of the informal activity is crucial in the registration process. It appears that informal enterprises located in the Daloa and San-Pedro zones are more 
determined to register than those in Abidjan. Indeed, the fact that the business is located in Daloa and SanPedro increases the probability that it will start the registration process by $21 \%$ and $5.9 \%$ respectively.

This may be because Daloa's informal activities are more visible than those in Abidjan, where firms can easily hide during inspections. Thus, the regular control of visible activities obliges the operators to proceed with their declaration. The more visible the company is, the more it is subject to pressure from tax officials and the greater the propensity of the manager to register it. This argument is reinforced by Rakotomanana (2009), who shows that managers who are more " visibles " are much more likely to want to regularize their entries in administrative registers. A similar result was found by Mouko (2015) who shows that the degree of formalization of Micro, Small and Medium Enterprises (MSMEs) is important in rural and semi-urban towns compared to large cities.

In addition, the State of Côte d'Ivoire has granted advantages to investments made on Ivorian territory. These advantages vary according to the location of the investment. For this purpose, the Ivorian territory is divided into three zones (A, B, C). These advantages, which are in line with the decentralization of economic activities, are more interesting in the less attractive zones (B and C). Given that Abidjan is in zone A and Daloa is in zone B, it is clear that firms in Daloa are more willing to formalize than those in Abidjan where the advantages provide less incentive to formalize.

The investment code requires, among other things, that the companies concerned keep regular accounts in accordance with the accounting laws and standards of the Organization for the Harmonization of Business Law in Africa (OHADA) and that they be subject to an effective tax regime. This incentive framework could explain why managers in Daloa (located in zone B) are more favorable to the formalization of their companies than those in Abidjan (located in zone A).

In addition, access to public infrastructure has a positive effect on managers' decisions to register their companies. The fact that a company has access to water and electricity increases the likelihood of registration by $6.8 \%$ compared to companies without access to these infrastructures. These infrastructures, especially electricity, are important factors of production for most informal production units. Access to water will not only boost activity, but could also be seen by operators as a counterpart to the possible costs of legality, anything that would encourage business registration. This result is corroborated by Rakotamanana's (2009) analysis, which indicates that access to basic public services increases the operator's propensity to want to establish contact with the administration. In this vein, Gelb et al. (2009) also find that firms opt for formality when access to public services is favorable.

The size of the production unit is decisive in the registration decision. The results indicate that small companies have a $49 \%$ higher chance of starting their recording compared to micro companies. This can be explained by the fact that larger companies tend to register with the state registers in order to take advantage of the opportunities related to their size. In addition, they tend to be more visible and therefore more subject to government control. The study by Levenson et al (1998) confirmed this result, showing that the decision to formalize the firm depends on its size, in the case of an analysis of Mexican microenterprises. Indeed, McKenzie et al (2006), argue that formality for microenterprises is irrelevant.

With regard to barriers to registration, the study identifies ignorance of procedures, the complexity of procedures and subcontracting as the main obstacles. Indeed, it appears that ignorance of procedures reduces the chance of registering a company by $14 \%$. In fact, due to the asymmetry of information, informal entrepreneurs have little or no information on the advantages, conditions and opportunities that they could benefit from by working more closely with the State. This finding is supported by Ouédraogo et al (2011), who showed that, in the main WAEMU conurbations, information asymmetry is a barrier to the formalization of informal firms, especially for IPUs below a certain critical size.

The complexity of procedures is an obstacle to the decision to register informal SMEs. Compared to managers who consider the procedures to be simple, those with complex procedures have less than $6.6 \%$ chance of starting the registration process. This negative effect of the complexity of procedures on the registration decision is mainly due to the costs incurred by long delays in registration, the cost of waiting for the registration to become effective and the losses incurred by stopping the activity due to the procedures. This result is attested to by Maldonado (2000), who finds that high registration costs and delays, 
the complexity of administrative procedures and the inadequacy of existing regulations to the needs of the informal sector are important factors that discourage microentrepreneurs from legalizing their businesses.

Informal firms that subcontract with formal firms are $8 \%$ less likely to register their businesses than those that do not subcontract with formal firms. Indeed, poor management of subcontracting can be an obstacle to small business development. First of all, it can lead to technical and commercial dependence on the activities subcontracted on both sides. Second, it can lead to low investments that generate little innovation for small firms. Finally, the company having subcontracted may have problems with delays in terms of deadlines but also risks of failure of the subcontractor preventing a fine response to customer requirements. All of the above can likely confine micro and small enterprises to informality. The negative effect of sub-contracting on the registration decision seems counter-intuitive because collaboration with large formal enterprises should enable informal entrepreneurs to be informed about the procedures and advantages of formalization and thus be more inclined to register their enterprises.

From a comparative perspective, it is important to note that the location and complexity of the procedures significantly influence both the registration decision and the formalization provision. However, it should be noted that variables such as goodwill, a business plan, and market access have a positive and significant effect on the willingness to formalize, but they have no significant effect on the registration decision. On the other hand, the level of education and corruption, which are variables likely to negatively influence our variables of interest, proved to be insignificant.

\section{CONCLUSION AND IMPLICATIONS}

The willingness of a manager to formalize his company would still not rhyme with its registration. In the same way, the factors of formalization differ from those of registration, as shown by the effect of identification variables. This paper tested the effect of identifying variables such as goodwill, business plan, market access and the age of the manager on the willingness to formalize and on the decision to register informal sector enterprises in Côte d'Ivoire. These variables have a significant effect on the willingness to formalize, but not a significant effect on the decision to register.

The econometric estimation of a Probit model with selection made it possible to determine the explanatory factors of MPEI registration. The data used are those of 400 enterprises in the informal sector surveyed as part of the CAPEC/IDRC project. All other things being equal, the location of the MPEI, ignorance and the complexity of the procedures explain both the formalization provision and the decision to register the enterprise. However, location, access to infrastructure, size of the MPEI and outsourcing practices boost MPEI registration. Conversely, information asymmetry and the complexity of procedures remain the main barriers to registration, thus confirming for these factors our hypothesis of a negative effect of the deleterious business environment on both the formalization provision and the MCCM registration decision.

Nevertheless, certain factors that are not significant in explaining the registration such as business assets, the possession of a business plan, the age of the manager and the narrowness of the market are determinants of the willingness to formalize. Thus, public authorities should focus strategies on registration levers. The analysis recommends, firstly, that strategies should be aimed primarily at larger informal firms, then the continuation of tax incentives in favor of regions where economic activities are less intense, in order to improve SME access to basic infrastructure considered as a factor of production, and the dematerialization of procedures. Ultimately, the dematerialization of procedures, the popularization of procedures and the advantages of formalization appear to be the levers that boost both the willingness to formalize and the decision to register.

\section{ACKNOWLEDGEMENT}

Translated \& Edited by American Publishing Services (https://americanpublishingservices.com/). 


\section{REFERENCES}

AGEPE. (2013). Enquête nationale sur la Situation de l'Emploi et du Travail des Enfants (ENSETE 2013). Agence d'Etudes et de Promotion d'Emploi. Retrieved from http://www.agepe.ci/etudespublications/176/enquete-nationale-sur-la-situation-de-l-emploi-etdutravail-des-enfantsensete-2013

AGEPE. (2012). Situation de l'Emploi en Côte d'Ivoire en 2012, Rapport d'Enquête Emploi auprès des ménages en Côte d'Ivoire en 2012, Agence d'Etudes et de Promotion d'Emploi. Retrieved September 8, 2014, from http://www.agepe.ci/etudespublications/176/enquete-nationale-sur-lasituation-de-1-emploi-et-dutravail-Agence d'Études et de Promotion d'Emploi/

Becttche, K.E., Fried, M., \& Marini, G. (2009). From the streets to markets: Formalization of street vendors in metropolitan Lima. Center for International private Enterprise, Case study no.0901.

Benjamin, C.N., \& Mbaye, A.A. (2012). Les entreprises informelles de l'Afrique de l'ouest francophone, Montreuil-France, AFD/Banque Mondiale. Retrieved June 20, 2017, from https://openknowledge.worldbank.org/bitstream/handle/10986/9364/9782744076602.pdf?sequenc $\mathrm{e}=5 /$

Branstetter, L.G., Lima, F., \& Venâncio, A. (2010). Do Entry Regulations Deter Entrepreneurship and Job Creation? Evidence from Recent Reforms in Portugal. NBER working paper 16473.

Bruhn, M. (2011). License to Sell: The effect of Business registration reform on Entrepreneurial Activity in Mexico. Review of Economics and Statistics, pp. 383-386.

CAPEC-MENAPME. (2016, October). Etude de faisabilité pour la mise en place du statut de l'entreprenant en Côte d'Ivoir. Rapport CAPEC-Ministère de l'Entrepreneuriat National de La Promotion des Pme et de l'Artisanat.

Dabla-Norris, E., Gradstein, M., \& Inchauste G. (2008). What causes firms to hide output? The Determinants of Informality. Journal of Development Economics, 85, 1-27.

De Mel, S., McKenzie, D., \& Woodruff, C. (2012). The Demand for, and Consequences of Formalization among Informal Firms in Sri Lanka. Washington, the World Bank, Policy Research Working Paper 5991, p.37.

De Soto, H. (1994). L'autre sentier: La révolution informelle dans le Tiers-Monde. La découverte, Paris.

De Soto, H. (1989, January 1). The other path: The invisible revolution in the Third World (1st Edition). New York: Harpercollins.

Djankov S., La Porta, R., Lopez-De-Silanes, F., \& Shleifer, A. (2002, February). The regulation of entry. The Quarterly Journal of Economics, CXVII.

ENSESI. (2016). Rapport descriptif sur la situation de l'emploi. Tome 1.

Fajnzylber, P., Maloney, W.F., \& Montes-Rojas, G. (2006). Does formality improve micro-firm performance? Quasi-experimental evidence from the Brazilian SIMPLES program. Washington, World Bank Policy Research Working Paper.

Farrell, D. (2004). The hidden dangers of the informal economy. McKinsey Quarterly, 3, 27-37.

FMI. (2017). Perspectives Economiques Régionales - Afrique sub-saharienne: Faire redémarrer la croissance. IMF 2017, Édition française (C2017 Fonds monétaire international.

Fomba, K., N'Dachi, D., Kengne, K., \& Ebella, R. (2013). Réglementation et Performances des Micros, Petites et Moyennes Entreprises Camerounaises. Yaoundé, Cameroun, Rapport de Recherche du FRCIEA N $\mathrm{N}^{\circ} 72 / 13$.

Friedman, E., Johnson, S., Kaufmann, D., \& Zoido-Lobaton, P. (2000). Dodging the grabbing hand: The determinant of unofficial activity in 69 countries. Journal of Public Economics, 76, 459-493.

Gelb, A., Taye, M., Vijaya, R., \& Manju, K.S. (2009). To Formalize or Not to Formalize? Comparisons of Microenterprise Data from Southern and East Africa. Washington, Center for Global Development, Working Paper 175.

Heckman, J.J. (1979). Sample Selection Bias as a Specification Error. Econometrica, 47(1), 153-61. Econometric Society. 
Ingram, M., Vijaya, R., \& Vyjayanti, D. (2007). Why Do Firms Choose to Be Informal? Evidence from Enterprise Surveys in Africa. Washington, Banque mondiale.

Institut National de la Statistique. (2017). Rapport final: Enquête Régionale Intégrée sur l'Emploi et le Secteur Informel (ERI-ESI), Côte d'Ivoire. Retrieved from http://www.uemoa.int/fr/rapport-finalenquete-regionale-integree-sur-l-emploi-et-le-secteur-informel-eri-esi-cote-d-ivoire

Ishengoma, E., \& Kappel, R. (2006). Economic growth and poverty: Does formalisation of informal enterprises matter? Hamburg, German Institute of Global and Area Studies: GIGA Working Paper-20/2006.

Johnson, S., Kaufmann, D., \& Zoido-Lobatón P. (1998). Corruption, Public Finances and the Unofficial Economy. World Bank Policy Research Working Paper Series, No. 2169. The World Bank, Washington, D.C.

Kanbur, R. (2009). Conceptualizing Informality: Regulation and Enforcement. Indian Journal of Labour Economics, 52(1).

Klapper, L., Amit, R., Mauro, F.G., \& Quesda, J.M. (2007). Entrepreneurship and Firm formation across countries. Washington, Word Bank, policy research working paper 4313.

La Porta, R., \& Schleifer, A. (2011). The Unofficial Economy in Africa. NBER Working Paper, 16821. https://doi.org/10.3386/w16821

Lapeyre, F. (2014). Les politiques publiques face à l'indocilité du local. In F. Lapeyre \& A. Lemaire, Sous la Direction de, 2014, Politiques publiques et pratiques de l'économie informelle en Afrique Subsaharienne. Louvain-la-Neuve: Academia - L'Harmattan.

Lautier, B. (1994). L'économie informelle dans le tiers monde, coll. Repères, éd. La Découverte.

Levenson, A.R., \& Maloney, W.F. (1998). The informal sector, firm dynamics and institutional participation. World Bank Policy Research, Working Paper 1988. Retrieved from http://documents.worldbank.org/curated/en/199771468757482154/The-informal-sector-firmdynamics-and-institutional-participation

Maldonado, C., Badiane, C., \& Mielot, A-L. (2004). Méthodes et instruments d'appui au secteur informel en Afrique francophone, Genève, OIT. Document de Travail, 24, 168.

Maloney, W.F. (2004). Informality Revisited. World Development, 32(7), 1159-1178.

McKenzie, D., \& Woodruff, C. (2006). Do entry costs provide an empirical basis for poverty traps? Evidence from Mexican microenterprises. Economic Development and Cultural Change, 55, 3-42.

Mouko J.P. (2015). Les dynamiques de l'économie informelle en Afrique subsaharienne: Une étude empirique de transition structurelle des micros-entreprises en République du Congo. Thèse de doctorat en science de gestion à l'université de Versailles Saint-Quentin en Yvelines (UVSQ).

North D.C. (1990). Institutions institutional Change and Economic Performance. Cambridge University, Press Cambridge.

Ouédraogo, E., Koriko, O., Coulibaly, S.Z., Fall, M., Ramilison, E., \& Lavallée, E. (2011). Les barrières institutionnelles à la formalisation des unités de production informelles dans les principales agglomérations des Etats membres de l'UEMOA. Document de travail de la Banque Mondiale.

Ouédraogo, I.M. (2017). Governance, Corruption, and the Informal Economy. Modern Economy, 8, 256271.

Perry, G.E., Maloney, W.F., Arias, O.S., Fajnzylber, P., Mason, A.D., \& Saavedra-Chanduvi, J.B.M. (2007). Informality: Exit and exclusion (English). World Bank Latin American and Caribbean studies. Washington, DC: World Bank. Retrieved from http://documents.banquemondiale.org/curated/en/326611468163756420/Informality-exit-andexclusion/

Rakotomanana, F.H. (2009). Les déterminants de la volonté de faire enregistrer son entreprise informelle à Madagascar. Quelles implications sur les stratégies de l'administration publique? Sateco, 104, 7590.

Sarr, S., Cisse, D.A., \& Haidara S.M. (1999). Le dialogue Etat - Secteur informel au Mali. Document de travail UNESCO 1999. 
Steel, W.F., \& Snodgrass, D. (2008). Raising Productivity and Reducing Risks of Household Enterprises: Diagnostic Methodology Framework. World Bank Africa Region Analysis on the Informal Economy. Washington, DC: World Bank.

Talbot, D. (2008, October). Les institutions créatrices de proximités: Institutions as creators of proximities. Revue d'Économie Régionale \& Urbaine, (3), 289-310. doi:10.3917/reru.083.0289

Traoré, N. (2021, January). Durée moyenne de fiscalisation des entreprises en Côte d'Ivoire. Revue Française d'Economie et de Gestion, 2(1), 25-51. https://doi.org/10.5281/zenodo.4441137

Traoré, N. (2020, November). Des fondements théoriques à la redéfinition du secteur informel dans la littérature économique. In P. Sariette, A.M. Batibonak, \& Nkuku (Dir.), Economie informelle et emplois en Afrique. Regards des sciences sociales et économiques, Yaoundé ed Monange.

Traore, N. (2019, December). Institutional constraints to the decision to formalize informal SMEs in Côte d'Ivoire. Revue Internationale de Gestion et d'Économie, SERIE B - ECONOMIE, 3(7), 4-25.

Traoré, N. (2016). Les déterminants de la disposition des managers à formaliser les PME informelles en Côte d'Ivoire. Études Caribéennes, 35. Retrieved December 2019, from http://etudescaribeennes.revues.org/10358. DOI : 10.4000/etudescaribeennes.1035/

Van de Ven, W.P.M.M., \& Van Pragg, B.M.S. (1981). The demand for deductibles in private health insurance: A probit model with sample selection. Journal of Econometrics, 17(2), 229-252.

Verick, S.D. (2006). The Impact of Globalization on the Informal Sector in Africa. Economic and Social Policy Division, United Nations Economic Commission for Africa and Institute for the Study of Labor.

Walther, R. (2007). La formation professionnelle en secteur informel. Notes et Documents $\mathrm{n}^{\circ} 33$, AFD, Paris.

\section{APPENDIX 1 : ECONOMETRIC RESULTS OF PROBIT WITH SELECTION}

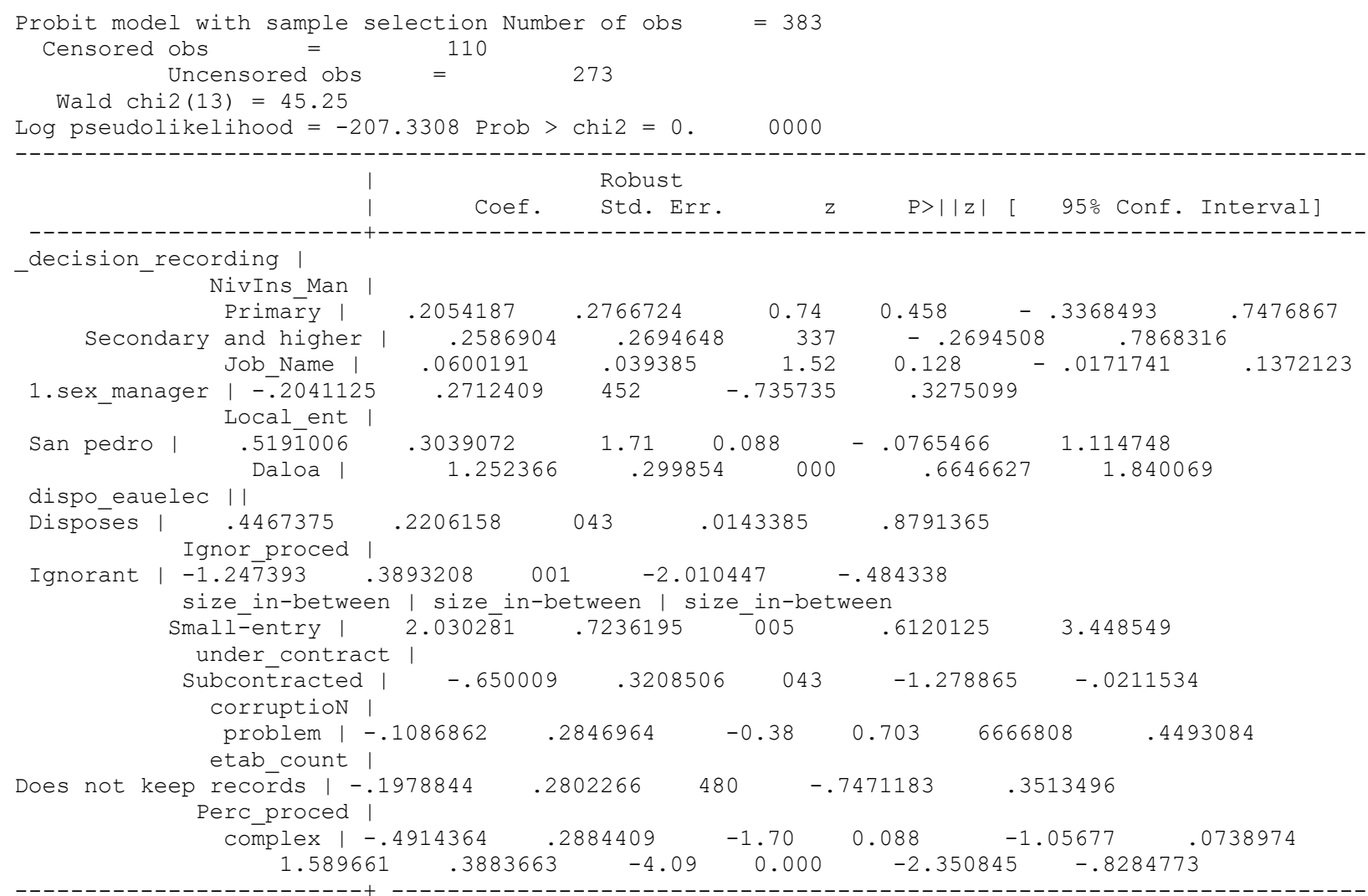




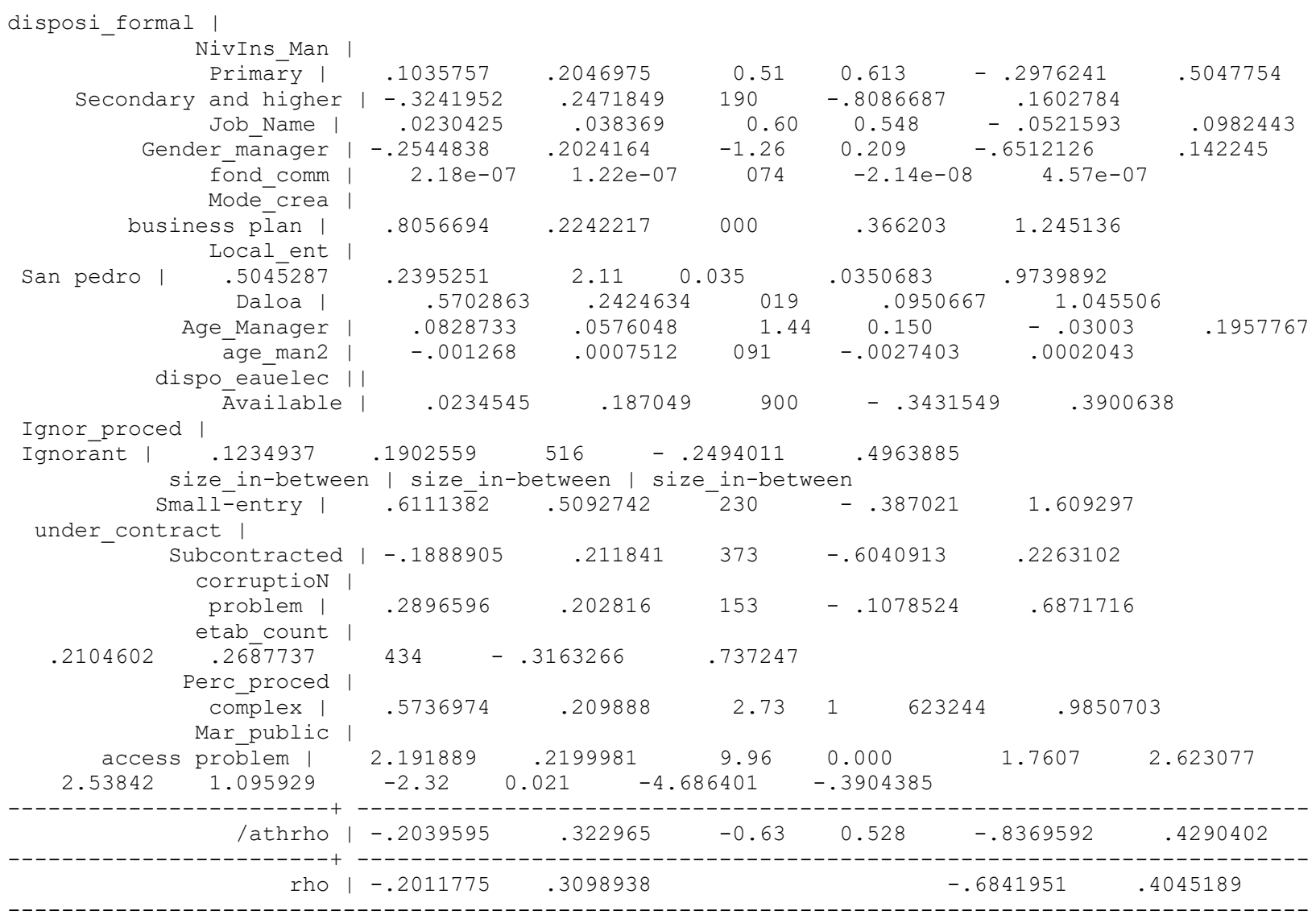

26 Journal of Applied Business and Economics Vol. 23(5) 2021 


\section{APPENDIX 2: MARGINAL EFFECTS PROBIT WITH SELECTION}

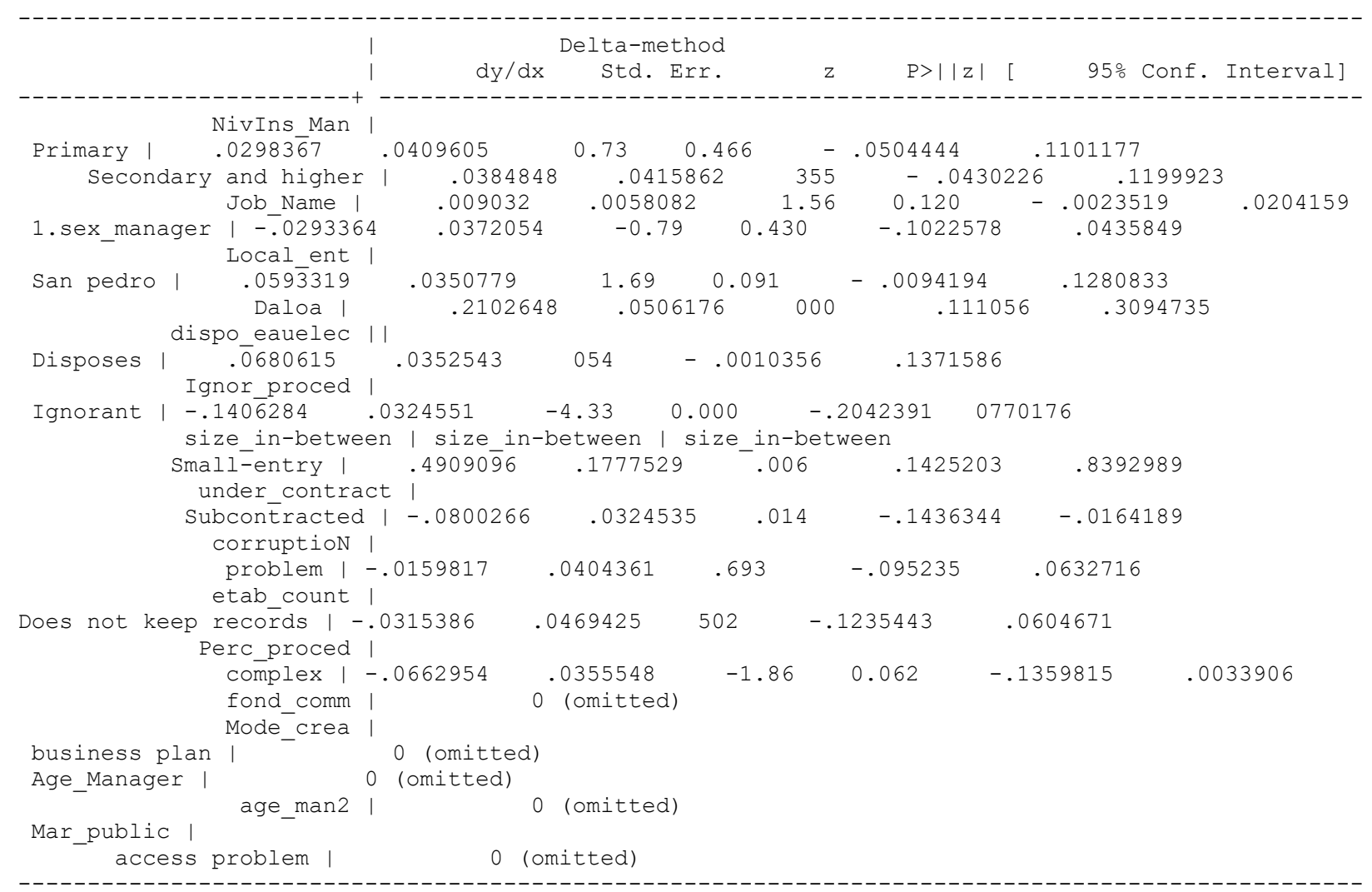

Note: dy/dx for factor levels is the discrete change from the base level. 


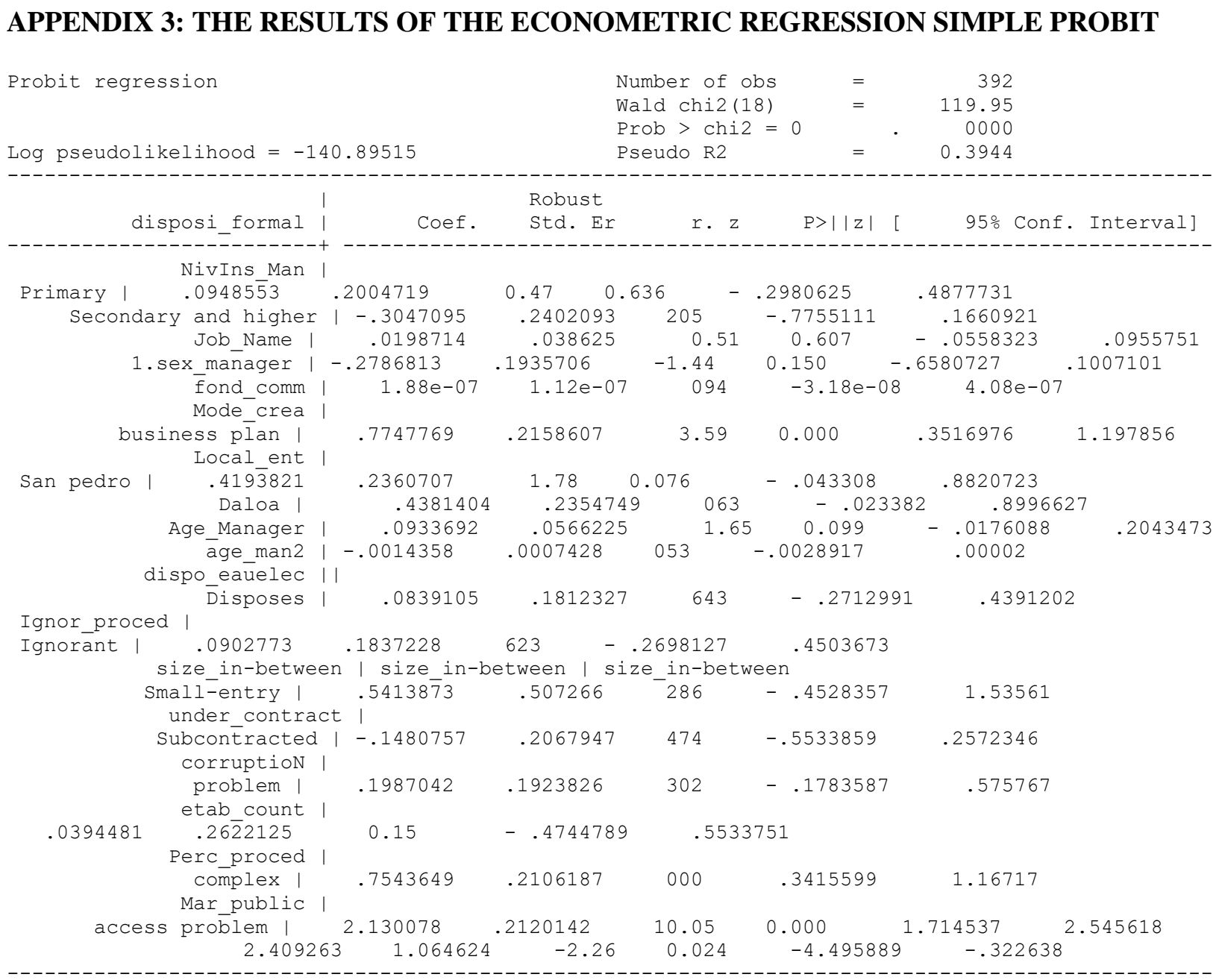




\section{APPENDIX 4: MARGINAL EFFECTS SINGLE PROBIT}

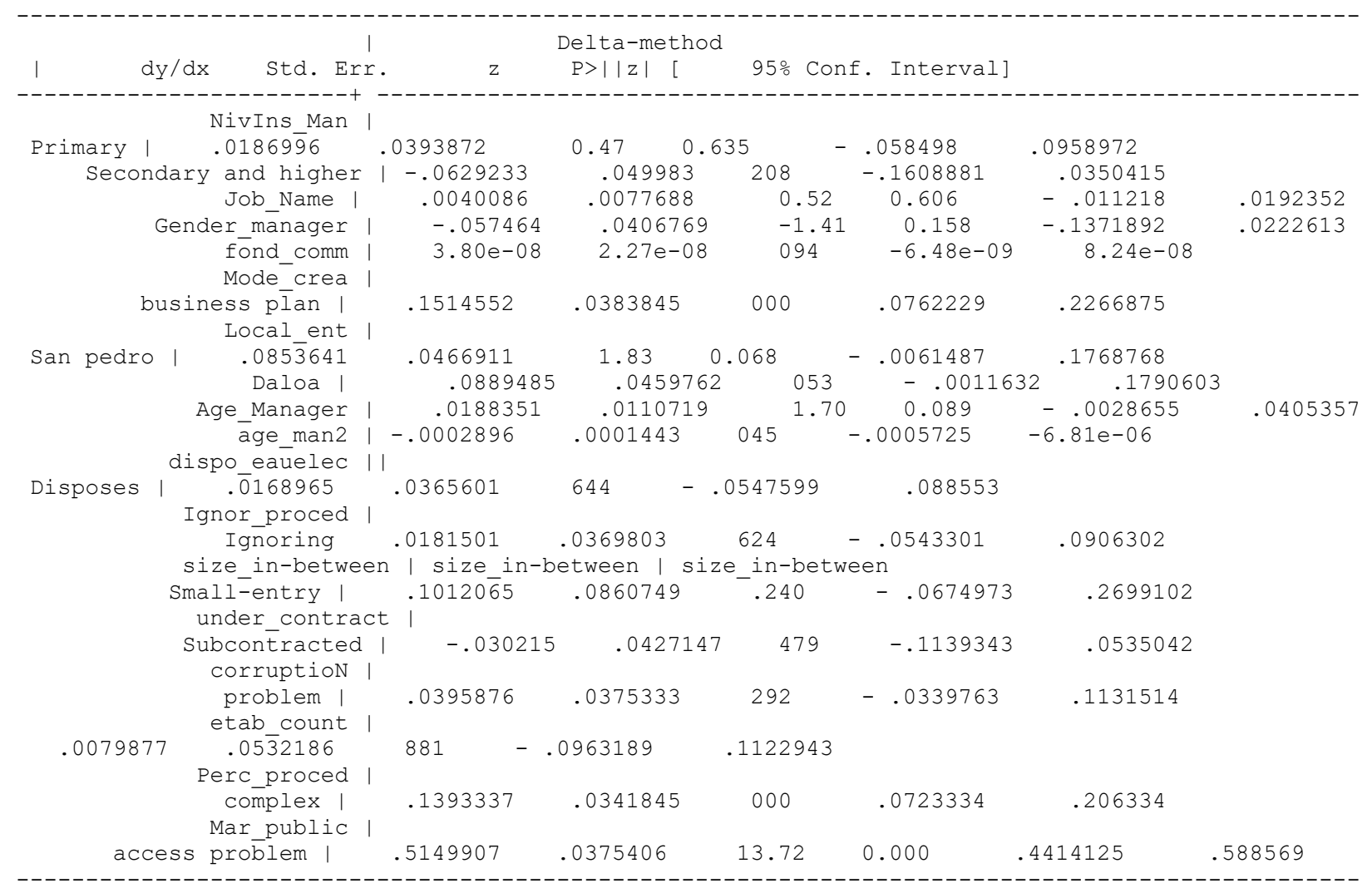

Note: dy/dx for factor levels is the discrete change from the base level. 